\title{
ANTIHYPERGLYCEMIC AND ANDROGENIC PROPERTIES OF Moringa oleifera LEAVES AQUEOUS EXTRACT ATTENUATE SEXUAL DYSFUNCTION IN DIABETES-INDUCED MALE RATS
}

\author{
NURUL AIN KAMAR BASHAH ${ }^{1}$ and MAHANEM MAT NOOR ${ }^{1}$ \\ ${ }^{1}$ Sperm Science and Biotechnology Laboratory, Faculty of Science and Technology, \\ Universiti Kebangsaan Malaysia, Selangor, Malaysia \\ *E-mail: mahanem@ukm.edu.my
}

Accepted 28 October 2021, Published online 30 November 2021

\begin{abstract}
Moringa oleifera leaves were essential for lowering blood glucose levels and increasing androgen levels. This study evaluates the antihyperglycemic properties of Moringa oleifera (MO) leaves aqueous extract and its effect on diabetes-induced male Sprague Dawley rats in attenuating sexual dysfunction. A total of 40 mature male rats were divided into four main groups which were normal control group that received $1 \mathrm{~mL}$ of distilled water, the negative control group which did not receive any treatment, positive control group that received $500 \mathrm{mg} / \mathrm{kg}$ body weight of metformin, and MO treated group that received $400 \mathrm{mg} / \mathrm{kg}$ body weight of Moringa oleifera leaves aqueous extract. All groups were analyzed after 14 and 21 days for their fasting blood glucose level (FBGL) and sexual behavior (mounting latency and mounting frequency). Analysis of testosterone level was also conducted using the testosterone kit of enzyme-linked immunosorbent assay (ELISA). The data of the treatment group were compared to the control group subjected to one-way ANOVA using IBM SPSS Statistics 22 analysis. The FBGL of diabetes-induced rats treated with Moringa oleifera leaves aqueous extract significantly decreased $(p<0.05)$ and the plasma testosterone level increased $(p<0.05)$ compared to the negative and positive control groups. Diabetesinduced rats treated with Moringa oleifera leaves aqueous extract also showed a significant decrease $(p<0.05)$ in mounting latency and increase $(p<0.05)$ in mounting frequency within 15 min of the observation period. This study demonstrated that Moringa oleifera leaves aqueous extract could reduce FBGL significantly and improve the sexual dysfunction of diabetesinduced male rats.
\end{abstract}

Key words: Antihyperglycemic, diabetes, Moringa oleifera, sexual dysfunction, sexual behavior, testosterone

\section{INTRODUCTION}

Diabetes mellitus is a disease that could affect male reproductive system and sexual function (García-Diez et al., 1991; Baccetti et al., 2002; Scarano et al., 2006; Agbaje et al., 2007; Mallidis et al., 2009; NavarroCasado et al., 2010; Kanter et al., 2012). A prolonged diabetes condition could lead to sexual dysfunction such as impairing the testosterone level and sexual activity (Scarano et al., 2006), causing impotence, and lowering libido (Maatman et al., 1987; Fode et al., 2012; Lert-Amornpat et al., 2017). According to Raina et al. (2007), a man with reproductive health problems couldn't have a quality sexual life (Raina et al., 2007). The mechanism of male physical arousal has been discussed in terms of protein phosphorylation level in which the level has been observed to be higher

* To whom correspondence should be addressed. before and during arousal (Wang et al., 2007). Therefore, it can be said that protein phosphorylation plays an important role in the production of sperm and testosterone (Fardilha et al., 2011; Yamashita et al., 2011). Drugs such as sildenafil citrate (Viagra), phosphodiesterase type 5 (PDESS), Levitra (vardenafil), Cialis (tadalafil), and levodopa had been widely used as sexual enhancers (Soni et al., 2012; Singh et al., 2013; Singh et al., 2013). However, these drugs are expensive and may cause side effects (Mirone et al., 2009; Aliferis et al., 2012). Researchers claim that local herbs are more effective and inexpensive. Besides, they have been widely used as therapeutic medicines to improve health. People believe that certain medicinal plants have aphrodisiac properties that could benefit male reproductive health (Singh et al., 2010; Malviya et al., 2011). Moringa oleifera (Family: Moringaceae) is a well-known medicinal plant that has been used traditionally due 
to its antimicrobial (Rahman et al., 2010; Elgamily et al., 2016), antihyperglycemic (Tuorkey, 2016; Paula et al., 2017), anticancer (Gismondi et al., 2013), aphrodisiac (Suresh et al., 2009; Prabsattroo et al., 2012; Prabsattroo et al., 2015; Shokry et al., 2020), and anti-inflammation (Adedapo et al., 2015; Arulselvan et al., 2016) properties. Its leaves contain a high concentration of zinc, potassium, phosphorus, selenium, calcium, vitamin A, vitamin C, vitamin D, and essential amino acids (Mahmood et al., 2010; Mishra et al., 2011). However, the potential of Moringa oleifera leaves extract to attenuate sexual dysfunction has not been fully explored. Therefore, this study aims to investigate the effects of Moringa oleifera leaves aqueous extract on fasting blood glucose level (FBGL), testosterone level, and sexual performance in diabetes-induced male rats.

\section{MATERIALS AND METHODS}

\section{Procurement and preparation of Moringa oleifera leaves aqueous extract}

Dried leaves powder was purchased from HERBAGUS SDN BHD, Pulau Pinang, Malaysia, and was verified by a botanist at the Herbarium Laboratory, Faculty of Science and Technology, Universiti Kebangsaan Malaysia (UKM) for its authenticity. A voucher specimen (UKMB 40344) was also given for reference purposes. The powder $(400 \mathrm{~g})$ was extracted with $4800 \mathrm{~mL}$ of distilled water (1:12) by using the reflux method for $3 \mathrm{~h}$ at $60^{\circ} \mathrm{C}$. Then, the extract yield was filtered using No. 1 Whatman filter paper and stored at $-80^{\circ} \mathrm{C}$ for 3 days before it was freeze-dried.

\section{Experimental animals}

A total of 40 proven fertile male Sprague Dawley rats (200-300 g) at the age of 12 weeks were used in this study. The animals were purchased from the Animal House, Universiti Kebangsaan Malaysia, and were kept individually in polycarbonate cages under laboratory conditions (12 hr light/dark cycle). They were given ad libitum access to water and food (Barastock Rat and Mouse Pellet Feed, Australia). The rats were divided into four groups consisting of five rats in each group $(n=5)$. The first group consisted of healthy rats which received $1 \mathrm{~mL}$ of distilled water, the second group consisted of untreated diabetes-induced rats, the third group consisted of diabetes-induced rats that were treated with $500 \mathrm{mg} / \mathrm{kg}$ body weight of metformin, and the fourth group consisted of diabetes-induced rats that were treated with $400 \mathrm{mg} / \mathrm{kg}$ body weight of Moringa oleifera leaves extract. The treated groups were orally administrated for 14 and 21 consecutive days. Before the induction of streptozotocin (STZ) via intravenous injection at a dose of $50 \mathrm{mg} / \mathrm{kg}$ body weight, the animals were fasted for $16 \mathrm{~h}$ but were given access to water. After 7 days of STZ induction, FBGL was measured. Animals with FBGL values more than $13 \mathrm{mmol} / \mathrm{L}$ were considered diabetic and were immediately used in the study, marking the start of the treatment (Day 0). On Day 15 and 22, the FBGL values in each group were measured again. The blood was drawn from the distal end of the tail vein and was measured using a glucometer. The experimental procedure in this study was conducted according to the ethical guidelines given by the Animal Ethics Committee Faculty of Medicine, UKM (FST/2017/MAHANEM/29-MARCH/833-MARCH2017-FEB.-2019).

\section{Sexual behavior test}

Mature female rats were brought in receptive by intramuscular injection of estradiol benzoate (20 $\mu \mathrm{g} / \mathrm{g}$ body weight) for $48 \mathrm{~h}$ and followed with progesterone ( $1 \mathrm{mg} / \mathrm{g}$ body weight) for $4 \mathrm{~h}$. A vagina smear was then performed to determine the estrus stage. Then, the female rats were placed individually with the male rats for $5 \mathrm{~min}$ in a cage under faint light in the laboratory. Sexual behavior test was then conducted. Mounting latency (time taken for the male rats to mount onto the back of female rats for the first time) and mounting frequency (number of mounts) was recorded within the 15 min observation period.

\section{Plasma testosterone analysis}

After the sexual behavior test was completed, the male rats were sacrificed and their blood samples were collected via cardiac puncture. The samples were kept in EDTA tubes and were centrifuged at 2500 r.p.m. for $10 \mathrm{~min}$. The plasma collected was kept in a dry tube at $-80^{\circ} \mathrm{C}$ until further use. The plasma testosterone level was measured using the testosterone enzyme-linked immunosorbent assay (ELISA) kit (No: 582701, Cayman, USA) by the standard protocol supplied by the company. The absorbance values were taken at $405 \mathrm{~nm}$ on a microplate reader and the values were expressed in $\mathrm{pg} / \mathrm{mL}$.

\section{Statistical analysis}

The data of the treatment group were compared to the control group subjected to one-way ANOVA using IBM SPSS Statistics 22 analysis (SPSS Inc., Chicago, IL, USA). Results were expressed as mean \pm SEM and were considered significantly different at $p<0.05$. 


\section{RESULTS}

\section{Fasting blood glucose level (FBGL)}

The FBGL values obtained after 14 and 21 days of treatment are presented in Table 1. There are significant differences $(p<0.05)$ in FBGL between all groups throughout the experiment. Oral administration of Moringa oleifera leaves extract shows a significant reduction in FBGL after 14 days of treatment where the result obtained $(11.32 \pm 1.71$ $\mathrm{mmol} / \mathrm{L})$ is lower than the value before treatment $(24.58 \pm 1.76 \mathrm{mmol} / \mathrm{L})$. Similarly, there is a reduction in FBGL after 21 days of treatment where the value after treatment is $12.52 \pm 2.07 \mathrm{mmol} / \mathrm{L}$, lower than the value before treatment $(17.36 \pm 3.18 \mathrm{mmol} / \mathrm{L})$. The FBGL in diabetes-induced rats treated with the antidiabetic drug, metformin, also shows a decrease after 14 and 21 days of treatment $(11.48 \pm 1.64$ $\mathrm{mmol} / \mathrm{L}$ and $13.22 \pm 0.81 \mathrm{mmol} / \mathrm{L}$, respectively). However, the negative control group showed higher FBGL throughout 14 days $(25.42 \pm 2.74 \mathrm{mmol} / \mathrm{L})$ and 21 days $(23.66 \pm 0.89 \mathrm{mmol} / \mathrm{L})$ of treatment. Meanwhile, the normal control group sustains the normoglycemic effects for both treatment periods.

\section{Assessment of sexual behavior test}

Table 2 shows the analysis of sexual behavior tests within the observation period (15 $\mathrm{min})$ after 14 and 21 days of treatment. As shown in Table 2, mounting latency (ML) and mounting frequency (MF) in all experimental rats after 14 days of treatment show significant differences $(p<0.05)$. However, after 21 days of treatment, there are still significant differences $(p<0.05)$ in ML but very slight differences in MF. Diabetes-induced rats treated with Moringa oleifera leaves extract to show a significant decrease in ML $(2.38 \pm 0.91 \mathrm{~min})$ and an increase in MF $(6 \pm 0.37)$ after 14 days of treatment compared to negative and positive control groups. Similarly, after 21 days of treatment, there is a decrease in ML $(4.85 \pm 1.38 \mathrm{~min})$ and an increase in MF $(4 \pm 0.80)$, better compared to the negative and positive control groups. Meanwhile, the negative control group shows an increase in ML (12.03 $\pm 1.82 \mathrm{~min}$ and 15.00 $\pm 0.00 \mathrm{~min})$ and a decrease in MF $(1 \pm 0.20$ and $0 \pm 0.00$ ) after 14 and 21 days of treatment, respectively.

\section{Analysis of testosterone level}

All groups show significant differences $(p<0.05)$ in testosterone levels after 14 and 21 days of treatment (Table 3). The group treated with Moringa oleifera shows a significant increase in testosterone level after 14 and 21 days of treatment $(114.88 \pm 9.51$ $\mathrm{pg} / \mathrm{mL}$ and $288.56 \pm 4.15 \mathrm{pg} / \mathrm{mL}$, respectively). On the contrary, the negative control group shows a

Table 1. FGBL values before and after administration of treatment

\begin{tabular}{|c|c|c|c|c|}
\hline \multirow{3}{*}{ Group } & \multicolumn{4}{|c|}{ Fasting blood glucose level (mmol/L) } \\
\hline & \multicolumn{2}{|c|}{14 days } & \multicolumn{2}{|c|}{21 days } \\
\hline & Day 0 & Day $15^{\text {th }}$ & Day 0 & Day $22^{\text {nd }}$ \\
\hline Normal control & $4.56 \pm 0.22$ & $4.48 \pm 0.69$ & $4.42 \pm 0.15$ & $4.88 \pm 0.50$ \\
\hline Negative control & $20.70 \pm 1.13$ & $25.42 \pm 2.74$ & $19.86 \pm 2.73$ & $23.66 \pm 0.89$ \\
\hline Positive control & $26.22 \pm 1.73$ & $11.48 \pm 1.64$ & $24.38 \pm 3.30$ & $13.22 \pm 0.81$ \\
\hline MO treated & $24.58 \pm 1.76$ & $11.32 \pm 1.71^{\mathrm{a}}$ & $17.36 \pm 3.18$ & $12.52 \pm 2.07^{a}$ \\
\hline
\end{tabular}

Data were expressed as mean \pm SEM. Significant $(p<0.05)$ with respect to ${ }^{a}=$ negative control. Day 0 : before administration of treatment; Day $15^{\text {th }} \& 22^{\text {nd }}:$ FBGL was measured.

Table 2. The analysis of sexual behavior test

\begin{tabular}{|c|c|c|c|c|}
\hline \multirow{3}{*}{ Group } & \multicolumn{4}{|c|}{ Sexual behavior test } \\
\hline & \multicolumn{2}{|c|}{14 days } & \multicolumn{2}{|c|}{21 days } \\
\hline & $\mathrm{ML}(\min )$ & MF & $\mathrm{ML}(\min )$ & MF \\
\hline Normal control & $2.45 \pm 0.73$ & $3 \pm 0.45$ & $0.87 \pm 0.25$ & $3 \pm 0.58$ \\
\hline Negative control & $12.03 \pm 1.82$ & $1 \pm 0.20$ & $15.00 \pm 0.00$ & $0 \pm 0.00$ \\
\hline Positive control & $9.23 \pm 1.43$ & $2 \pm 0.20$ & $10.60 \pm 1.26$ & $1 \pm 0.45$ \\
\hline MO treated & $2.38 \pm 0.91^{a, b}$ & $6 \pm 0.37^{a, b}$ & $4.85 \pm 1.38^{a, b}$ & $4 \pm 0.80^{\mathrm{a}, \mathrm{b}}$ \\
\hline
\end{tabular}

Data were expressed as mean \pm SEM. Significant $(p<0.05)$ with respect to ${ }^{a}=$ negative control and ${ }^{b}=$ positive control. ML: Mounting latency; MF: Mounting frequency. 
Table 3. The analysis of testosterone level

\begin{tabular}{lcc}
\hline \multirow{2}{*}{ Group } & \multicolumn{2}{c}{ Testosterone level $(\mathrm{pg} / \mathrm{mL})$} \\
\cline { 2 - 3 } & 14 days & 21 days \\
\hline Normal control & $180.06 \pm 11.11$ & $181.72 \pm 8.02$ \\
Negative control & $64.30 \pm 6.54$ & $38.60 \pm 5.16$ \\
Positive control & $103.42 \pm 8.46$ & $152.06 \pm 13.89$ \\
MO treated & $114.88 \pm 9.51^{\mathrm{a}}$ & $288.56 \pm 4.15^{\mathrm{a}, \mathrm{b}}$ \\
\hline
\end{tabular}

Data were expressed as mean \pm SEM. *Significant concerning positive and negative controls $(p<0.05)$.

decrease in testosterone level after 14 and 21 days of treatment $(64.30 \pm 6.54 \mathrm{pg} / \mathrm{mL}$ and $38.60 \pm 5.16$ $\mathrm{pg} / \mathrm{mL}$, respectively).

\section{DISCUSSION}

This study shows that Moringa oleifera leaves aqueous extract at a dose of $400 \mathrm{mg} / \mathrm{kg}$ body weight can reduce FBGL after 14 and 21 days. A study conducted by Bamagous et al. (2018) has shown that the administration of ethyl acetate fraction of Moringa oleifera leaves extract at $200 \mathrm{mg} / \mathrm{kg}$ body weight reduced the serum glucose level of diabetesinduced rats (Bamagous et al., 2018). This suggests that Moringa oleifera leaves extract possesses antihyperglycemic properties due to the contribution of the bioactive compounds in the plant such as kaempferol, quercetin, and chlorogenic acid (Olayaki et al., 2015). According to El-Moez et al. (2014) and Chuang et al. (2007), kaempferol can decrease blood glucose levels as well as improve insulin resistance. Besides, kaempferol tends to stimulate glucose uptake. Meanwhile, quercetin can inhibit the activity of GLUT 2 in transporting glucose and fructose to the brain and stimulate GLUT 4 translocation in the skeletal muscle (Chuang et al., 2007; El-Moez et al., 2014). This study also shows that the rats in the negative control group had no sexual interest where they showed the longest ML and the lowest MF within the 15 min observation period after 14 and 21 days. This might be due to the low testosterone level of the rats as shown in Table 3. The oral administration of Moringa oleifera leaves extract showed more persistent sexual activity compared to other control groups. According to Prabsattroo et al. (2012) and Prabsattroo et al. (2015), Moringa oleifera leaves extract can improve sexual performance. The increase in ML may be associated with sexual motivation while the decrease in MF may reflect the sexual desire and performance of the treated group (Yakubu et al., 2011; Kataria et al., 2013). In the male reproductive system, androgen acts as an important sexual modulator in terms of libido and erection (Morelli et al., 2006; Jiafeng et al., 2011). The main hormone for androgen is testosterone which is produced by the interstitial Leydig cells in the testis. High production of testosterone could increase sexual motivation, sexual desire, and sexual performance (McGinnis et al., 1989; Aversa \& Fabbri, 2001; Gonzales et al., 2003; Lüpez et al., 2007). In this study, the group treated with Moringa oleifera showed higher testosterone levels and this is by the study done by Syarifuddin et al. (2017), and ElDesoky et al. (2017), and Khalifa et al. (2016) on Bali bulls and rabbit bucks, respectively. Besides, the administration of Moringa oleifera leaves chloroform and hydro-alcoholic extract have also been proven to increase the testosterone level of the experimental subjects (El-Sheikh et al., 2016; Chatterjee et al., 2017). This might be due to the androgenic properties of the bioactive compounds in the plant. A previous study has also claimed that the presence of saponin could enhance the androgen level (Gauthaman et al., 2008). In addition, the presence of alkaloids, terpenes, and xanthones in the plant extract could enhance the aphrodisiac activity in male rats (Paz et al., 1979; Taha et al., 1995; Drewes et al., 2002; Estrada-Reyes et al., 2013). The study conducted by Moichela et al. (2020) showed the antioxidant compound in aqueous extract of Moringa oleifera leaves could maintain human sperm function. Therefore, the increase of plasma testosterone level in this study might be due to the presence of these bioactive compounds in Moringa oleifera leaves aqueous extract. In the future, this study will be a focus on the metabolomic study as well as the identification of bioactive compounds in aqueous extract of Moringa oleifera leaves on antihyperglycemic, fertility, and libido of diabetes male Sprague Dawley rats. In addition, the treatment group of Moringa oleifera leaves aqueous extract will be added into few groups compared to the current study.

\section{CONCLUSION}

The oral administrations of $400 \mathrm{mg} / \mathrm{kg}$ body weight of Moringa oleifera leave aqueous extract reduced the fasting blood glucose level suggesting good antihyperglycemic activity in the diabetes-induced rats. Moringa oleifera leaves aqueous extract increased the testosterone level as well as the aphrodisiac activity inferring that androgen has the property that benefits male reproductive health particularly those with a diabetic condition.

\section{ACKNOWLEDGEMENTS}

We would like to express our extended gratitude to the Faculty of Pharmacy, Faculty of Medicine, Faculty of Health Science, and Faculty of Science and Technology, Universiti Kebangsaan Malaysia. This 
study was supported by the Faculty of Science and Technology, Universiti Kebangsaan Malaysia (grant number: GUP-2020-084).

\section{REFERENCES}

Adedapo, A.A., Falayi, O.O. \& Oyagbemi, A.A. 2015. Evaluation of the analgesic, anti-inflammatory, anti-oxidant, phytochemical and toxicological properties of the methanolic leaf extract of commercially processed Moringa oleifera in some laboratory animals. Journal of Basic and Clinical Physiology and Pharmacology, 26(5): 491-499.

Agbaje, I.M., Rogers, D.A., McVicar, C.M., McClure, N., Atkinson, A.B., Mallidis, C. \& Lewis, S.E.M. 2007. Insulin dependent diabetes mellitus: Implications for male reproductive function. Human Reproduction, 22(7): 1871-1877.

Aliferis, K., Petropoulos, I.K., Farpour, B., Matter, M.A. \& Safran, A.B. 2012. Should central serous chorioretinopathy be added to the list of ocular side effects of phosphodiesterase 5 inhibitors? Ophthalmologica, 227(2): 85-89.

Arulselvan, P., Tan, W.S, Gothai, S., Muniandy, K., Fakurazi, S., Mohd Esa, N., Alarfaj, A.A. \& Kumar, S.S. 2016. Anti-inflammatory potential of ethyl acetate fraction of Moringa oleifera in downregulating the NF-kB signaling pathway in lipopolysaccharide-stimulated macrophage. Molecules, 21(1452): 1-13.

Aversa, A. \& Fabbri, A. 2001. New oral agents for erectile dysfunction: what is changing in our practice. Asian Journal of Andrology, 3: 175-179.

Baccetti, B., La Marca, A., Piomboni, P., Capitani, S., Bruni, E., Petraglia, F. \& De Leo, V. 2002. Insulindependent diabetes in men is associated with hypothalamo-pituitary derangement and with impairment in semen quality. Human Reproduction, 17(10): 2673-2677.

Bamagous, G.A., Al Ghamdi, S.S., Aziz Ibrahim, I.A., Mahfoz, A.M., Afify, M.A., Alsugoor, M.H.M., Shammah, A.A., Arulselvan, P. \& Rengarajan, T. 2018. Antidiabetic and antioxidant activity of ethyl acetate extract fraction of Moringa oleifera leaves in streptozotocin-induced diabetes rats via inhibition of inflammatory mediators. Asian Pacific Journal of Tropical Biomedicine, 8(6): 320-327.

Chatterjee, P.K., Anantharaya, V.N.M., Shiva, R.K., Kumar, N.A., Shetty, S.B., Budihal, S.V., Bhat, M.R. \& Kunal 2017. Pre and post-treatment effects: estimation of serum testosterone and lipid peroxidation levels on Moringa oleifera extract induced cadmium exposed rats. Pharmacognosy Journal, 9(6): 846-849.
Chuang, P.H., Lee, C.W., Chou, J.Y., Murugan, M., Shieh, B.J. \& Chen, H.M. 2007. Anti-fungal activity of crude extracts and essential oil of Moringa oleifera Lam. Bioresource Technology, 98: 232-236.

Drewes, S.E., Horn, M.M., Munro, O.Q., Dhlamini, J.T.B., Meyer, J.J.M. \& Rakuambo, N.C. 2002. Pyrano-isoflavones with erectile-dysfunction activity from Eriosema kraussianum. Phytochemistry, 59: 739-747.

El-Desoky, N.I., Hashem, N.M., Elkomy, A. \& Aboelezz, Z.R. 2017. Physiological response and semen quality of rabbit bucks supplemented with Moringa leaves ethanolic extract during summer season. Animal, 11(9): 1549-1557

Elgamily, H., Moussa, A., Elboraey, A., EL-Sayed, H., Al-Moghazy, M. \& Abdalla, A. 2016. Microbiological assessment of Moringa oleifera extracts and its incorporation in novel dental remedies against some oral pathogens. Open Access Macedonian Journal of Medical Sciences, 4(4): 585-590.

El-Moez, S.I.A., El-Badawi, A.Y. \& Omer, H.A.A. 2014. Assessment of antimicrobial effect of Moringa: in vitro and in vivo evaluation. African Journal of Microbiology Research, 8(42): 36303638.

El-Sheikh, S.M., Khairy, M.M.A., Abdel Fadil, H., Azza, M.A. \& Abo-Elmaaty. 2016. Ameliorative effect of Moringa oleifera extract on male fertility in paroxetine treated rats. Zagazig Veterinary Journal, 44(3): 244-250.

Estrada-Reyes, R., Carro-Juárez, M. \& Martínez-Mota, L. 2013. Pro-sexual effects of Turnera diffusa Wild (Turneraceae) in male rats involves the nitric oxide pathway. Journal of Ethnopharmacology, 146: 164-172.

Fardilha, M., Esteves, S.L.C., Korrodi-Gregorio, L., Vintém, A.P., Domingues, S.C., Rebelo, S., Morrice, N., Cohen, P.T.W., da Cruz e Silva, O.A.B. \& da Cruz e Silva, E.F. 2011. Identification of the human testis protein phosphatase 1 interactome. Biochemical Pharmacology, 82: 1403-1415.

Fode, M., Krogh-Jespersen, S., Brackett, N.L., Ohl, D.A., Lynne, C.M. \& Sønksen, J. 2012. Male sexual dysfunction and infertility associated with neurological disorders. Asian Journal of Andrology, 14: 61-68.

García-Diez, L.C., Hernandez, J.J.C., Hernandez-Diaz, J., Pedraz, M.J. \& Miralles, J.M. 1991. Semen characteristics and diabetes mellitus: significance of insulin in male infertility. Archives of Andrology, 26: 119-127. 
Gauthaman, K. \& Ganesan, A.P. 2008. The hormonal effect of Tribulus terrestris and its role in the management of erectile dysfunction - an evaluation using primates, rabbit and rats. Phytomedicine, 15: 44-54.

Gismondi, A., Canuti, L., Impei, S., Di Marco, G., Kenzo, M., Colizzi, V. \& Canini, A. 2013. Antioxidant extracts of African medicinal plants induce cell cycle arrest and differentiation in B16F10 melanoma cells. International Journal of Oncology, 43: 956-964.

Gonzales, G.F., Córdova, A., Vega, K., Chung, A., Villena, A. \& Góñez, C. 2003. Effects of Lepidium meyenii (Maca) a root with aphrodisiac and fertility enhancing properties, on serum reproductive hormone levels in adult health men. Journal of Endocrinology, 176: 163-168.

JiaFeng, C., PengYing, Z., ChengWei, X., TaoTao, H., YunGui, B. \& KaoShan, C. 2012. Effect of aqueous extract of Arctium lappa L. (burdock) roots on the sexual behavior of male rats. $B M C$ Complement and Alternative Medicine, 12: 1-8.

Kanter, M., Aktas, C. \& Erboga, M. 2012. Protective effects of quercetin against apoptosis and oxidative stress in streptozotocin-induced diabetic rat testis. Food and Chemical Toxicology, 50: 719-725.

Kataria, S., Kaur, D., Rao, S.K. \& Khajuria, R.K. 2013. In vitro and in vivo aphrodisiac properties of Corchorus depressus Linn. on rabbit corpus cavernosum smooth muscle relaxation and sexual behaviour of normal rats. Journal of Ethnopharmacology, 148: 210-217.

Khalifa, W.H., Ibrahim, F.M., El Makawy, A.I., Sharaf, H.A., Khalil, W.K.B. \& Maghraby, N. 2016. Safety and fertility enhancing role of Moringa oleifera leaves aqueous extract in New Zealand rabbit bucks. International Journal of Pharmacy, 6(1): 156-168.

Lert-Amornpat, T., Maketon, C. \& Fungfung, W. 2017. Effect of Kaempferia parviflora on sexual performance in streptozotocin-induced diabetic male rats. Andrologia, e12770: 1-6.

Lüpez, H.H., Wurzel, G. \& Ragen, B. 2007. The effect of acute bupropion on sexual motivation and behavior in the female rat. Pharmacology, Biochemistry and Behavior, 87: 369-379.

Maatman, T.J., Montague, D.K. \& Martin, L.M. 1987. Erectile dysfunction in men with diabetes mellitus. Urology, 29(6): 589-592.

Mahmood, K.T., Mugal, T. \& Ul Haq, I. 2010. Moringa oleifera: A natural gift-a review. Journal of Pharmaceutical Science and Research, 2(11): 775-781.

Mallidis, C., Agbaje, I.M., Rogers, D.A., Glenn, J.V.,
Pringle, R., Atkinson, A.B., Steger, K., Stitt, A.W. \& McClure, N. 2009. Advanced glycation end products accumulate in the reproductive tract of men with diabetes. International Journal of Andrology, 32: 295-305.

Malviya, N., Jain, S., Gupta, V.P. \& Vyas, S. 2011. Recent studies on aphrodisiac herbs for the management of male sexual dysfunction - a review. Acta Poloniae Pharmaceutica-Drug Research, 68(1): 3-8.

McGinnis, M.Y., Mirth, M.C., Zebrowski, A.F. \& Dreifuss, R.M. 1989. Critical exposure time for androgen activation of male sexual behavior in rats. Physiology \& Behavior, 46: 159-165.

Mirone, V., Fusco, F., Rossi, A., Sicuteri, R. \& Montorsi, F. 2009. Tadalafil and vardenafil vs. sildenafil: A review of patient-preference studies. BJU International, 103(9): 1212-1217.

Mishra, G., Singh, P., Verma, R., Kumar, S., Srivastav, S., Jha, K.K. \& Khosa, R.L. 2011. Traditional uses, phytochemistry and pharmacological properties of Moringa oleifera plant: An overview. Der Pharmacia Lettre, 3(2): 141-164.

Morelli, A., Filippi, S., Vignozzi, L., Mancina, R. \& Maggi, M. 2006. Physiology of erectile function: an update on intracellular molecules processes. EAU-EBU Update Series, 4: 96-108.

Moichela, F.T., Adefolaju, G.A., Henkel, R.R. \& Opuwari, C.S. 2020. Aqueous leaf extract of Moringa oleifera reduced intracellular ROS production, DNA fragmentation and acrosome reaction in Human spermatozoa in vitro. Andrologia, 53: e13903.

Navarro-Casado, L., Juncos-Tobarra, M.A., CháferRudilla, M., Iniguez De Onzono, L., BlázquezCabrera, J.A. \& Miralles-Garcia, J.M. 2010. Effect of experimental diabetes and STZ on male fertility capacity. Study in rats. Journal of Andrology, 31(6): 584-592.

Olayaki, L.A., Irekpita, J.E., Yakubu, M.T. \& Ojo, O.O. 2015. Methanolic extract of Moringa oleifera leaves improves glucose tolerance, glycogen synthesis and lipid metabolism in alloxaninduced diabetic rats. Journal of Basic and Clinical Physiology and Pharmacology, 26(6): 585-593.

Paula, P.C., Sousa, D.O.B., Oliveira, J.T.A., Carvalho, A.F.U., Alves, B.G.T., Pereira, M.L., Farias, D.F., Viana, M.P., Santos, F.A., Morais, T.C. \& Vasconcelos, I.M. 2017. A protein isolate from Moringa oleifera leaves has hypoglycemic and antioxidant effects in alloxan-induced diabetic mice. Molecules, 22(271): 1-15.

Paz, G. \& Homonnai, Z.T. 1979. Leydig cell function in streptozotocin-induced diabetic rats. Experientia, 35: 1412-1413. 
Prabsattroo, T., Wattanathorn, J., Iamsa-ard, S., Muchimapura, S. \& Thukhummee, W. 2012. Moringa oleifera extract attenuates male sexual dysfunction. American Journal of Neuroscience, 3(1): 17-24.

Prabsattroo, T., Wattanathorn, J., Iamsaard, S., Somsapt, P., Sritragool, O., Thukhummee, W. \& Muchimapura, S. 2015. Moringa oleifera extract enhances sexual performance in stressed rats. Journal of Zhejiang University, Science, $B$ (Biomedicine and Biotechnology), 16(3): 179190.

Rahman, M.M., Rahman, M.M., Akhter, S., Jamal, M.A., Pandeya, D.R., Haque, M.A., Alam, M.F. \& Rahman, A. 2010. Control of coliform bacteria detected from diarrhea associated patients by extracts of Moringa oleifera. Nepal Medical College Journal, 12(1): 12-19.

Raina, R., Pahlajani, G., Khan, S., Gupta, S., Agarwal, A. \& Zippe, C.D. 2007. Female sexual dysfunction: classification, pathophysiology, and management. Fertility and Sterility, 88(5): 1273 1284.

Scarano, W.R., Messias, A.G., Oliva, S.U., Klinefelter, G.R. \& Kempinas, W.G. 2006. Sexual behaviour, sperm quantity and quality after short-term streptozotocin-induced hyperglycaemia in rats. International Journal of Andrology, 29: 482-488.

Shokry, D.M., Badr, M.R., Orabi, S.H., Khalifa, H.K., El-Seedi, H.R. \& Abd Eldaim, M.A. 2020. Moringa oleifera leaves extract enhances fresh and cryopreserved semen characters of Barki rams. Theriogenology, 153: 133-142.

Singh, B., Gupta, V., Bansal, P., Singh, R. \& Kumar, D. 2010. Pharmacological potential of plant used as aphrodisiacs. International Journal of Pharmaceutical Science Review and Research, 5(1): 104-113.

Singh, R., Ali, A., Jeyabalan, G. \& Semwal, A. 2013a. Current status of Indian medicinal plants with aphrodisiac potential. Journal of Acute Disease, 4: $13-21$

Singh, R., Ali, A., Gupta, G., Semwal, A. \& Jeyabalan, G. 2013b. Some medicinal plants with aphrodisiac potential: A current status. Journal of Acute Disease, 1: 179-188.
Soni, D.K., Sharma, V., Chauhan, N.S. \& Dixit, V.K. 2012. Effect of ethanolic extract of Paederia foetida Linn. leaves on sexual behavior and spermatogenesis in male rats. Journal of Men's Health, 9(4): 268-276.

Suresh, S., Prithiviraj, E. \& Prakash, S. 2009. Doseand time-dependent of ethanolic extract of Mucuna pruriens Linn. seed on sexual behavior of normal male rats. Journal of Ethnopharmacology, 122: 497-501.

Syarifuddin, N.A., Toleng, A.L., Rahardja, D.P. \& Ismartoyo Yusuf, M. 2017. Improving libido and sperm quality of Bali bulls by supplementation of Moringa oleifera leaves. Media Penternakan, 40(2): 88-93.

Taha, S.A., Ageel, A.M., Islam, M.W. \& Ginawi, O.T. 1995. Effects of (-) cathinone a psychoactive alkaloid from khat (Catha edulis Forsk) and caffeine on sexual behavior in rats. Pharmacological Research, 31(5): 299-303.

Tuorkey, M.J. 2016. Effects of Moringa oleifera aquoeus leaf extract in alloxan induced diabetic mice. Interventional Medicine \& Applied Science, 8(3): 109-117.

Wang, D., Noda, Y., Tsunekawa, H., Zhou, Y., Miyazaki, M., Senzaki, K. \& Nabeshima, T. 2007. Behavioural and neurochemical features of olfactory bulbectomized rats resembling depression with comorbid anxiety. Behavioural Brain Research, 178: 262-273.

Yakubu, M.T. \& Akanji, M.A. 2011. Effect of aqueous extract of Massularia acuminata stem on sexual behaviour of male wistar rats. Evidence-Based Complementary and Alternative Medicine, 2011: 738103.

Yamashita, S., Tai, P., Charron, J., Ko, C.M. \& Ascoli, M. 2011. The Leydig cell MEK/ERK pathway is critical for maintaining a functional population of adult Leydig cells and for fertility. Molecular Endocrinology, 25: 1211-1222. 
